\title{
Wyrób tymbyłów w Trokach 1
}

\author{
ARON SZPAKOWSKI
}

Zbliża się święto tymbyłów. Trzeba przygotować śmietankę, mleko i jaja. Gospodynie troszczą się, gdzie znaleźć najlepszą śmietankę i chodzą do sklepów, szukając, gdzie znajdą najlepszą mąkę: pierwszy gatunek (sortę). Potem już się znalazła u kogoś śmietanka. Gospodyni spieszy się, by jak najprędzej piec, aby nie skwaśniała jej śmietanka.

Wówczas szuka, gdzieżby znaleźć przyrządy potrzebne do robienia tymbyłów. A bardzo wiele przyrządów do tego potrzeba. U jednego gospodarza znajduje tałky, u drugiego naczynie do mieszania (mąki na) tymbyły, u trzeciego „skrytulkę" (radełko) i "liżę" (łopatę do pieca), u czwartego wałki i „cziumiawiucz" (lub „cziumiuwiucz" — łopatkę do ciasta).

Teraz przygotowują drzewo, suche, brzozowe. Skoro to wszystko jest już zebrane, proszą kilka panien (dziewcząt) do roboty. Zebrawszy się wszyscy w jedno miejsce, zaczynają przesiewać mąkę i troszczą się, kto będzie mieszał. Znajduje się ktoś i mówi: „ja będę mieszał".

Zaczyna się robienie tymbyłów. Jeden ${ }^{2}$ miesza, drugi dolewa śmietanki, czy to mleka, trzeci nosi drwa do pieca i kładzie ogień, czwarty bierze się do tałky. Co wychodzi z mieszania, to dają na tałky i to już się wyrabia (za pomocą tałky). Wyrabia się długo: patrzą, aby było dobrze wygniecione. Gospodyni ucina z boku kraj i przypatruje się: jeżeli niema dziurek, to znajdują, że (ciasto) już gotowe. Proszą jednego, żeby zaczął krajać. Krając, rozpościerają ręcznik i (na nim) układają (dosł. rozścielają) rzędami. Potem zaczynają formować. Jedni formują, drudzy wałkują, a gospodyni prosi, żeby nie robili bardzo dużych (tybyłów). Wywałkowane (tymbyły) dają „skrytułkarzowi" (temu co ma radełko), który to młody człowiek z silną ręką na to czeka. Od „skrytułkarza" odbiera (tymbyły) młoda dziewczynka i rozściela na desce szeregami, przykrywając każdy szereg ręcznikiem.

1Tadeusz Kowalski, Przyczynki do etnografii i dialektologii karaimskiej. Rocznik orientalistyczny. 1927 T. 5, s. 204-205 (tłumaczenie z jęz. karaimskiego, pisownia oryginalna [red.]).

20czywiście można też tłumaczyć „,jedna", wobec braku rozróżniania rodzaju gramatycznego w karaimskim. 
Gospodyni patrzy na piec i prosi: „spieszcie się z robotą, bo już piec gotów". Kładący do pieca wymiata piec czystem pomiotłem (miotła, którą się robi do wymiatania pieca). Wymiótłszy wzywa: „dajcie jednen tymbył, żeby zobaczyć, czy piec nie pali". Kiedy się wsadzi do pieca, zdarza się, że gorący piec pali; wówczas trzeba, zamaczawszy w wodzie miotłę, nieco ostudzić piec. Kładą się tymbyły do pieca: najpierw tymbyły na wodzie, potem na śmietanie, a na ostatku idą do pieca tymbyły na jajach. Kiedy wychodzą z pieca, to gospodyni bierze i układa (dosł. rozściela) na chłodnem miejscu, póki wszystkie nie wyjdą z pieca. Kiedy wszystkie (tymbyły jednego gatunku) wyjdą z pieca, gospodyni oczyszcza (zamiata) mace ręcznikiem i nosi do szafy, a z pozostałemi zaczynają robić tak samo, jak pierwsze były robione.

Kiedy skończą piec tymbyły gospodyni nastawia samowar i ugaszcza pomocników herbatą, a niektóre (drugie) gospodynie gotują tutmač3 i dają jeść, jakby po wielkiej pracy.

W wigilję święta spieszą iść wieczorem na modlitwę, a gospodynie, zostawszy w domu, przygotowują maror (gorzkie korzenie). Wróciwszy z modlitwy, zasiadają $\mathrm{w}$ domu z całą rodziną do stołu, na którym gospodyni przygotowała potrawy obrzędowe. Znajdują się na stole tymbył, pieczeń, jaja i nieco gorzkich korzeni - chrzan, rzodkiew, cebula, pieprz i sól, tudzież wino do błogosławieństwa. Gospodarz odczytuje aggadę. Skończywszy aggadę, odmawia (dosł. czyni) błogosławieństwo nad winem, z którego wszyscy kosztują, a potem odmawia (dosł. czyni) błogosławieństwo nad wszystkiem tem, co się znajduje no stole. Potem zaczyna się jedzenie. Pojadłszy do syta, jedzą kompot, po wszystkiem bywa znów błogosławieństwo, po którem idą spać.

${ }^{3}$ Po karaimsku makaron, kluski. 